\title{
The Physical Education and Sport Studies in the Framework of Social Demands- Institutional Structuring and Teacher Training the Developments Before and During Turkey Training Community Alliance Period (1922 - 1936)
}

\section{Murat ÖZMADEN ${ }^{1}$ \\ Fikret SOYER ${ }^{2} \bowtie(1)$ \\ Harun ÖZMADEN ${ }^{s}$}

'Department of Coaching, Adnan Menderes University, Aydın, Turkey

Email:muratozmaden@yahoo.com Tel: +905535057661

'Department of Physical Education and Sport Teaching, Faculty of Sports Sciences, Sakarya University, Sakarya,

Turkey

Email:fikretsoyer@gmail.com Tel:+905325478982

${ }^{3}$ Free Researcher, Bursa, Turkey

Email:harun.ozmaden@hotmail.com Tel:+905053470575

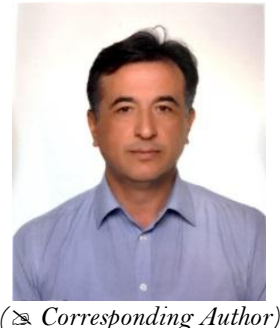

Abstract

The purpose of this study was to evaluate the physical education and sports studies and institutional structuring, the developments before and during Turkey Training Community Alliance (TTCA) Period in the framework of social demands within the historical process. In the study, the screening model was taken as a basis, historical and descriptive methods were used. The periodicals belonging to the period of 1922-1936 were reviewed to address how TTCA activities in physical education and sport had influenced the social life, and what sort of discussions had been made about the subject. As a result, the physical education and sport are thought to be used as suitable tools for providing the physical and spiritual development as well as fulfilling the functions which would create powerful community; and it's seen that the effort was made to practice those ideas as much as possible.

Keywords: Turkey training community alliance, Teacher training, Physical education

JEL Classification: I29.

Citation | Murat ÖZMADEN; Fikret SOYER; Harun ÖZMADEN (2018). The Physical Education and Sport Studies in the Framework of Social Demands-Institutional Structuring and Teacher Training the Developments Before and During Turkey Training Community Alliance Period (1922 - 1936). Asian Journal of Education and Training, 4(3): 170-175.

History:

Received: 13 March 2018

Revised: 16 April 2018

Accepted: 20 April 2018

Accepted: 20 Ap

Licensed: This work is licensed under a Creative Common Attribution 3.0 License (oc)

Publisher:Asian Online Journal Publishing Group

\section{Contents}

1. Introduction

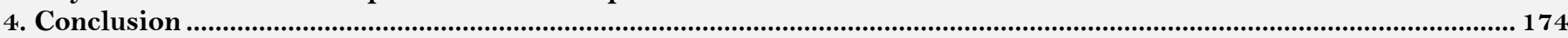

References.

Contribution/Acknowledgement: All authors contributed to the conception and design of the study.

Funding: This study received no specific financial support

Competing Interests: The authors declare that they have no conflict of interests.

Transparency: The authors confirm that the manuscript is an honest, The study was reported; that no vital study as planned have been explained.

Ethical: This study follows all ethical practices during writing. 


\section{Introduction}

Physical education and sport are defined as the movement forms that aim to develop people's physical strength and abilities at the same level of their mental and spiritual education. However, it is known that sport activities have been applied for various reasons during the historical process, and they have fulfilled quite different functions for both individuals and societies. In ancient times, providing a number of physical, mental and social qualities such as hunting to survive, being able to dominate the horse in different terrain conditions, being able to shoot moving objects while moving, predicting the movements of the prey, acting in harmony with the group, and conducting a group was not only economically important, but improved the military, administrative, social and athletic skills as well (Yıldıran, 1996).

In the Ottoman Empire, the sport, which were protected and encouraged till the regression period and institutionalized through private sport fields and lodges, began to lose importance in the early 18 th century. With the new regulations introduced with the Tanzimat, the application areas of traditional sports such as archery, wrestling and throwing javelin, which are supported by the state and the foundations, were narrowed down. Just as it was in the whole world, the industrial revolution also showed its effect in the Ottoman Empire, albeit slightly delayed. Increased relations with the West led to westerners bringing modern sport to the country towards the end of the 19th century.

However, due to the successive Balkan Wars, World War I and the War of Independence, serious sport events could not be organized. The fact that the physical and mental weakness of the Turkish youth who had been away from the concept of being in sportive activities for a long time was shown as one of the most important reasons for the failure in the Balkan Wars brought the idea of using the benefits of the physical education and sports back to the agenda. In such an environment, the first management organization of Turkish sport which was initially founded as a temporary committee in Istanbul in 1922, and the headquarter of which was taken to Ankara in 1923, was established, and then it went into action under the name of Turkey Training Community Alliance (TTCA) The organizational form of TTCA which was in the effort to be organized in the whole country, and which functions the sport studies fulfill have not been a research topic in a sufficient level.

It is thought that this study will be important in understanding to which social demands the physical education concept was oriented in the period of TTCA which is a unique part of our recent history, and in establishing a model for the researches on the historical descriptions of the physical education and sport studies of later periods. From here, it is important to know the development process of physical education and sports studies before and during TTCA period.

\section{Physical Education and Sport Activities in the Late Period of Ottoman Empire 2.1. School Programs and Institutional Structures}

School Physical Education and Sport Activities in Pre-Turkey Training Community Alliance Period Enderun School (school where government officials were educated) and Dervish Lodges (place of worship and education), which hosted sport activities under their roof indirectly and directly in Ottoman period, lost their functions with the Tanzimat. In general, these sport activities in the traditional sports context were replaced by the practices taken from the West both at the school and outside, or by the modern sports that were being put into practice by westerners themselves especially since the first Constitutional Monarchy. Firstly, in 1863, they were included in the curriculum under the title of Modern Gymnastics (Riyazat-1 Bedeniye) in the Turkish Military Academy and appropriate gym equipment was provided for the course (Kocer, 1970; Özçakır and Yıldıran, 2016). The main progress in the schools, on the other hand, was made in Galatasaray High School, which was established in 1868. After the Rescript of Gulhane (Tanzimat Fermanı), it was proposed to open new kind of schools by stating that a religious education system could not meet the needs of the day. With this in mind, in 1845, junior high schools (rüştiyeler), which educated students for specific areas such as education, military academy and medical school were started to open whereas in 1868 , common high schools were started to open. Galatasaray High School was established as the first high school (Kocer, 1970).

In 1862, bayonet and fencing lessons were introduced into the curriculum of military schools and these lessons were given by Kolağası (officer phase between the squadron leader and lieutenant in the Ottoman army) Mr. Akif Efendi (Tayga, 1990).

An Italian teacher named Martini was assigned to the Naval Academy as a gym class for the first time. Later in 1864 Sadik Bey was appointed as a gym teacher. It was thought that these courses, which continued just as exercises in the beginning, would be incomplete without a book, and military translator Colonel Mustafa Hami Bey was assigned to write a gymnastic book (Gökdağ, 1939).

In these years, while there was no physical education and gymnastics in the curriculum of the girls' teacher training schools, the gym class was introduced in the Naval Academy in 1884 (Unat, 1964). In Naval Academy, swimming science lessons were taught as well as applied courses (Kaplan, 1986). Students who had learned this lesson theoretically also learned it in a practical way with swimming suits and materials. Among the students who were educated, the first big name was Ali Faik (Üstünidman) Bey (Atabeyoğlu, 1985).

In Galatasaray High School (Mektebi Sultaniye), the first physical education teacher was a French person named Moireaux. Moireaux taught the gymnastics course known as "İdman ve Riyazet-i bedeniye (Workout and Gymnastics)" (Atabeyoğlu, 1972). Later, Moireaux was replaced by a French teacher named Curel. The first thing Curel made was to turn the part allocated to him in the school into a gym and to put the gym equipment he brought with him from France into the use of his students (Tekil, 1985; Doğan, 2010). In the following period, after the French teachers, Greek-origin Stangalli became the teacher of the school. It's seen that Stangali, whose main profession was doing acrobatics worked as a gymnastics teacher (Ergin, 1977). Stangali opened a gym in Beyoglu during his teaching period at Galatasaray High School and trained many students (Bilge, 1988). With the departure of Stangali in 1879, his student Ali Faik (Üstünidman) took up his position. Ali Faik Bey was the first Turkish gymnastics teacher of his time and remained in this position for 44 years until 1923 (Ergin, 1977). In the country, gymnastics lessons were practiced in the style of "Jahn-Amoros gymnastic" in those years. Regarding 
these classes, Selim Sirrı Tarcan stated: "There were rings, trapezes, ropes, bars, rope ladder, all of which were hanging from the ceiling, on one side, and fixed iron bars and shot puts in various weights on the other side. The aim expected from this class is to train strong athletes and acrobats having hard muscles " (Tarcan, 1928). Selim Sirrı Tarcan argued that physical education and gymnastics class in this period wasn't of value in terms of science and education, but merely was about talent, a skill (Ergin, 1977).

The founder of the Jahn-Amoros gymnastics, which were the first practices in Turkey as school physical education activities, is the Spanish Colonel Don Francesco Amoros (1770-1848). Amoros, who was influential in France's physical education for about thirty years, placed great importance on military gymnastics movements under the influence of Jahn. In Jahn gymnastics, much improvement was made in terms of the equipment used, as a consequence, parallel, bar, horse, ring were introduced into gymnastics as equipment by himself. In addition, widespread practices such as climbing, swinging, pulling, pushing, lifting, jumping and wrestling were widely practiced in Jahn's gymnastics (Mengutay, 1992). Amoros was accused of bringing a compelling method not suitable for gradual development by mixing each equipment and system he saw, and it was argued that only a few acrobats were satisfied with this method (Alpman, 1972). At the end of the nineteenth century, an increasing number of school-aged youngsters tended towards sports first at schools, then outdoors secretly in response to these programs, which resembled a complete military training exercise and aimed at strict discipline and blind obedience (Fisek, 1983).

In addition to being the school where the gymnastic lessons were applied as a modern sport activity for the first time, Galatasary High School was also the school in which the modern sports rather than gymnastics, particularly football, started to be practiced (Daver, 1929). As people who led Turkish Sport such as Selim Sirrı Tarcan, Faik Üstünidman, Vildan Aşır Savaşır were educated in Galatasaray High School; educators such as Selim Sabit, Hacı Mustafa and Şemsi Efendi placed importance on the physical education and sport, and defended the idea of including the sport in curriculum as a part of the education given at schools (Akyüz, 1985).

Thus, in accordance with this view, in Aşiret (tribe) school established in Istanbul in 1892, training lesson, "tâlim", was given to the first and fourth grades, and foot training lesson, "ayak tâlimi" was taught to the fifth grades (Ayaz, 1948). On the other hand, the sport branches such as basketball and water polo were popularized throughout Turkey for the first time by "Robert College", one of the foreign schools, in 1904, and the first competition was also held by this school (Alptekin, 1982).

Gymnastics lesson in the curriculum of Naval Academy, and military schools by getting necessary equipment and building facilities.

During the period of 1863-1903, when Moda, Elips, Imogene and Kadıköy clubs came together and founded Istanbul Football Alliance, physical education and sports histories were merged at schools and outside, and as a consequence, "sport" was integrated with the formal education system. In the 1870s, some running events were organized in Kağıthane district of Istanbul, amateurs gathered around football matches in which the English players played between 1885 and 1890 first in Izmir and then in Istanbul.

Later in 1908, the freedom atmosphere in the political and intellectual life, formed with the declaration of the Second Constitutional Monarchy (The period of the Ottoman Empire, which began with the Constitution of 1876 and lasted until the 1918 Mudros Armistice, called the First and Second Constitutional Periods) enabled education, physical education and sport lessons to develop positively.

Along with this revival in political life and intellectual life, the importance of increasing the number of students and teachers in education was emphasized. While the first higher education institution for girls was established during these periods, the life-related courses started to be given again in curriculums. Physical education and sports lessons were tried to be spread rapidly in regular schools and teacher training schools. In accordance with the Statute on General Education dated 1869 (Law regarding to Establish the Secondary School), high schools in which education was carried out in two three-year semesters were established. In every grade of these schools, sports lessons started to be given under the name of physical education for an hour a week. These lessons also started to be given as two hours in all grades (1st to 6th) of Galatasaray High School (Bilge, 1988).

Selim Sirrı Tarcan, who fully understood the importance of physical education and sports, opened the "Physical Education School" in a large commercial complex on the Mercan Hill towards the end of 1908. This private school with gymnastics, fencing, boxing and horseback riding in its program was not different from the schools that French gymnasts had previously opened. The school was able to continue its education until April 1909, as Selim Sirrı Tarcan went to Sweden to study physical education in May 1909. Having completed his physical education studies in Sweden, Tarcan returned to Turkey in 1910, left his military service and was appointed as "the whole Ottoman physical education inspector" on 14 July 1910. On January 19, 1911, Tarcan opened a new special quality "Physical Education School". Unlike the other schools, this second school provided applied and theoretical education such as Anatomy, Physiology, and Medical Knowledge with more scientific methods (Çapan, 1999). The most prominent feature of this period was the struggle between empirical gymnastics and Swedish gymnastics, which is a system. Even though these two approaches didn't improve sufficiently, they found practice. After all, Selim Sirrı Bey, who brought Swedish gymnastics to our country, made a lot of efforts for the dissemination of physical education lessons in schools and took an important place in the history of physical education (Batum, $1943)$.

In 1913, in the high school curriculum, physical education lesson was given in 6 th, 7 th, 8 th and 9 th grades, also in 10th, 11 th, 12 th grades (the second cycle of secondary education), and in Girls' High School as two hours a week. Moreover, in the curriculum of "Mektebi Íptidaiye-i Umumiye" (primary school) established in 1913, there were military exercise classes for male students along with the "Physical Education and School Games" course. In 1915, in the curriculum of the boys' and girls' high schools, students, in addition to the Physical Education classes for an hour a week, performed physical education, shooting exercises, and played educational games in the mornings and evenings on two or three days of the week determined by the school administration (Bilge, 1988).

During the period of the Second Constitutional Monarchy, in the curriculum published for the high schools in 1913 and 1915, physical education classes included Swedish exercises and games. In the curriculum published in 1915; Information on activities such as jumping, capturing, handball, discus and javelin throw, tug of war, running, 
hockey, tennis, swimming, rowing, cycling, fencing, soccer and sighting, all of which can be applied outside the lessons was also presented. On the basis of this information, during the period of the Second Constitutional Monarch, in formal curriculum published for high schools, it was suggested to apply Sweden gymnastics in physical education classes and English-style sports in times other than the school hours; and it was requested that no artistic gymnastics applied in previous periods be included. This pointed to the transformation that took place in the field of physical education. However, it is also conceivable that the teachers who worked at Galatasaray High School preferred the system which was suitable for their own understanding of physical education in terms of practice (Özçakır and Yıldıran, 2016).

The rapid development of physical education and sports lessons after having been put into schools' curriculum led to a need for teachers in this field. Therefore, in 1915, for the first time in Turkish sports history, a school was needed to train physical education teachers. This one-year school, which was affiliated to the higher teacher education school, the lessons of which were planned to be carried out as theoretical and applied lessons, could not be opened due to World War I (Unat, 1964).

\section{Physical Education and Sport Studies in Republican Period}

\subsection{Their Position in School Programs, and Institutional Structuring (TTCA 1923-1936)}

Turkey Training Community Alliance (TIC is) period School Physical Education Studies; with the proclamation of the Republic in Turkey, it was believed that making some changes and regulations which could respond to the needs of the community was necessary. In order to make progress and advance in sport, the importance of the physical education teacher was recognized, and it was stated, in the second article of TTCA statute, that a school of physical education which would have the task of educating trainers for the country should be established. On March 2, 1924, the Law on Unification of Education (Tevhid-i Tedrisat Kanunu) No 430 dated 1924 was adopted by Grand National Assembly of Turkey, and all educational institutions in the country were placed under the Ministry of Education. Unity in education was established, caliphate was abolished by the Law No 431, and dervish lodges and monastic institutions were abolished by the law No 677 and issued on November 30, 1925. On March 22, 1926, the permission to open a school was granted only to the state, the principles of education were determined, and most of the lessons taught during the Ottoman period were abolished (Arun, 1990).

With the establishment of the Republic, a high school was not considered as an advanced and complete high school unless it did not have a gymnastics lesson in its curriculum, Anonymous (1923). However, when it was the 1930 s, it was argued that the Sweden-style physical education activities which were used for enabling Turkey to have a place in sport in the developing world was not able to train the individual bodies adequately, and Ministry of National Education was asked to make some studies to abolish all those activities (Bedi, 1934). In 1930, the Ministry of National Education banned primary and secondary school students from going to sports clubs outside of schools and participating in competitions either as individuals or as teams, except for schools, with the "Regulation on Student Sports Organization at Schools". With this banning; formal private boys' high schools and teacher training schools as well as "student sports house" were established with the same regulation (Yucel, 1994). The revenues of these sports houses were the fees given by the students who were sports enthusiasts. With the help of the school administration, those fees increased. Expenses for sports equipment and sports activities were covered with this money (Anonymous, 1934).

In schools, although the physical education and sport class were available in all grades of primary schools, middle schools, and high schools for an hour a week, the universities didn't have it. Therefore, the activities of children and young people performed in company with specialists did not exceed one hour a week during the whole course of their education (Aşir, 1936). With the idea that Sweden Gymnastics which had been practiced for 20 years was no longer an option, it was expressed by the recent officials of that period that either younger and newer American or German gymnastics models would be practiced or a "Turkish Gymnastics Model" which would be more compatible with our national culture would be established (Fetgeri, 1931).

One important reason for discussions on physical education practices and systems was the inconveniences of Sweden-style gymnastics' Turkish way of practice. One of these inconveniences was that all students were expected to do the same movements as if they were a machine, regardless of their being weak, strong, sick, robust, large, or small, and only one teacher was allocated to 60-70 students. It was impossible for a teacher to control the movements that 60-70 students have done together, and made his/her students do each movement in the right way. Since the number of physical education teachers was not sufficient, it was necessary to increase the number of teachers in order to reach the goal (Fetgeri, 1931).

The Education Congress ("Maarif Kongresi"), which assembled in 1921 but then dissolved not having finished its studies, continued on between July 15 and August 15, 1923 following "the law on the establishment of secondary school", and passed into our history of education as the First Science Committee ("Birinci Heyet-i İlmiye") As a result of the work of this committee, the 6th article of the Cabinet's Decree is sued on August 14, 1923 reads: "Physical Education improves the moral abilities of the individual as well as his physical and mental abilities. For these purposes, a Physical Education Teacher Training School will be opened and the Scouting Organization will be renewed". As a result of taking that decision, the training of physical education teacher was designated as a "government task". Selim Sirrı Tarcan was appointed to this task so taht that this decision could be realized (Arun, 1990).

In order to meet the needs of physical education teachers and learn the methods that the European nation pursued in terms of physical education, in 1925, one student was sent to Germany and three students were sent to the Royal Higher Physical Education Institute in Stockholm, Sweden by the Ministry of National Education (Anonymous, 1947). Since it was not possible to meet the needs of physical education teachers in schools during the TTCA period, In 1926, when Mustafa Necati was the Minister of National Education, a course was opened to train physical education teachers for the first time for the purpose of minimizing the deficiency (Bilge, 1988). This course was opened so as to inform individuals who had received a license for physical education teacher in any way up to that time, and promote their professional development (Anonymous, 1947). 
The course was one year long and consisted of male and female classes. The course's curriculum included Physical Education Theories, Physiology, Anatomy, Foot Movement, Medical Knowledge, Sports Theories and Applied Courses (Bilge, 1988). Prospective teachers who had successfully completed girls' and teachers training school as well as talented, successful primary school teachers of each province were invited to the course along with the officers from the army and fire department who had certain characteristics (Aball, 1974).

Those who graduated from that course with the qualification certificate titled "Physical Education Teacher" were assigned to secondary schools. 148 boys and 63 girls graduated from these courses producing graduates for three years, and they were assigned to secondary schools. Due to the low number of secondary schools, the number of physical education teachers was considered adequate, and the training in those courses was stopped after 1930 (Güven, 1996).

Kur Dainas, a specialist physical education teacher from Germany, was appointed to Gazi Education Institute, the first institution that trained physical education teacher at the college level in Turkey, as a faculty member by the Ministry of Education. Meanwhile, Turkish physical education teachers started to teach physical education in various places of the country. Of these, Nizamettin Kırşan from Istanbul Teacher Training School, Vildan Aşır Savaşır from Galatasaray High School, and Zehra Alagöz from İsmet Paşa Girls' Institute, the department of physical education (after she completed her education) were brought to Gazi Education Institute. This institution, which only educated male physical education teachers until 1937, began to train female physical education teacher since then. In order to give lectures to female students, Margarate Korge, Istanbul German High School Female Physical Education Teacher, was sent to Berlin University, Physical Education Institute in Germany for three-year training after she had been selected as a teaching staff of the department (Güven, 1996). The period of study in Gazi Education Institute was three years at first. However, this practice was changed in the middle of 1937 because of the necessity of the physical education teacher in secondary education by reducing the period of study of the department from three to two. In the same year, students in the third year became physical education teacher as a graduate of "2.5" years in the second half of the year (Anonymous, 1947).

\section{Conclusion}

The influence of the culture on sports has been an ongoing phenomenon with different styles and effects throughout the ages. In this sense, Turkish sports have been fed from the living culture of the society and have come to this day, becoming diversified in proportion to its feeding rate. As Turkish sports involve basic cultural values, it is a social phenomenon that has the potential to transfer these values to the participants. Sport, as a social phenomenon, is a reflection of the socio-cultural system it is in. Turkish sport is a part of and complementary to the culture as it carries the characteristics of the society in which it is present and practiced.

Physical education and sports studies that experienced many stages; during the TTCA period, the inclusion of physical education and sports courses in all the schools and their rapid development created a need for teachers of this field. In order to meet the needs of the teachers, physical education teacher trainings were made both at home and abroad with the Republican government's financial and moral support.

Balkan Wars, World War I, and The War of Independence were considered as the reasons for orienting TTCA management to benefit from the positive effects of the physical education and sports on the physical and spiritual development. The Turkish nation who got tired during these wars and most of the young people who were called to the military was "sick, handicapped, hunchback and weak", and besides these physical negativities, there were immobility, half-heartedness and mental disorder which were considered as the worst of diseases in the society. It was thought that the TTCA management would fulfill the functions of "creating strong society" by correcting this situation.

Physical and mental disorders seen in the vast majority of society is naturally the greatest obstacle in front of the effort to create a strong society in social, economy and military sense. Therefore, physical education and sport are thought to be used as suitable tools for providing the physical and spiritual development as well as fulfilling the functions which would create powerful community.

\section{References}

Aball, A., 1974. Youth and sports. Ankara: GSB Publications. pp: 96.

Akyüz, M.N., 1985. Turkish education history. Ankara: Ankara University, Faculty of Educational Sciences. pp: 176, 263.

Alpman, C., 1972. The development through physical education and ages in the integrity of education. 5 th Edn., İstanbul: GSB Publications, Milli Eğitim Basımevi. pp: 176-178.

Alptekin, G., 1982. Encyclopedic sports world. Istanbul: Sailing Press. pp: 930.

Anonymous, 1923. High school sports. Spor Alemi, 5(3): 14-15.

Anonymous, 1934. School sports. Sports Post, 1(6): 6-8.

Anonymous, 1947. T.C. maarifi 1923-43 yılları maarifimiz. Ankara: Uludag Publications. pp: 119-120.

Arun, C., 1990. Physical education teachers in the era of the Republic of Turkey, and efforts growing stages. Sport Science Journal, 1: 9-10.

Aşir, V., 1936. School and sports. Istanbul: Turkish Sports Authority and Magazine.

Atabeyoğlu, C., 1972. Spor ansiklopedisi. Istanbul: New Istanbul Newspaper Publications. pp: 179.

Atabeyoğlu, C., 1985. Tanzimattan cumhuriyete spor, cumhuriyet encyclopedia of the Republic of Tanzimat. Ankara: İletişim Publications. pp: $1475-1507$.

Ayaz, N., 1948. National education institutions of the Republic of Turkey and histories. Ankara: National Education Press. pp: $550-551$

Batum, X.X., 1943. Physical education and sports in the Republic of Turkey. Ankara: Çankaya Press. pp: 11-40.

Bedi, M., 1934. Physical education and our country. Sport Post, 1(20): 10-14.

Bilge, N., 1988. Reared be of physical education teachers in Turkey. Ankara: Ministry of Culture Publications No: 1095. pp: 17-36.

Çapan, M.Ş., 1999. Selim sirgi in Turkish sports Tarcan. Muğla: Ünyay Publications. pp: 19-20.

Daver, A., 1929. Sporda gentlemanlik. Turkish Sports, 1(3): 3-4.

Doğan, İ., 2010. Main stages of Turkish education history. Ankara: Nobel Publishing.

Ergin, O., 1977. Turkey Maarif history. Istanbul: C.IV, Trace Press. pp: 1546-1547.

Ergin, O.N., 1977. History of Turkish education. İstanbul: Eser Press. pp: 1546.

Fetgeri, A., 1931. Turkish gymnastics. Turkish Sports, 2(3): 40-92.

Fisek, K., 1983. Sports in Turkey. Republican Era Turkey Encyclopedia, 8: 2177-2185.

Gökdağ, C., 1939. The entrance of physical therapy to schools. Physical Education and Sports, 1: 5-27. 
Güven, Ö., 1996. The republican Era in Turkey physical education and sports teacher training preparatory school of breeding studies. Journal of Physical Education and Sports Sciences, 7(2): 75-76.

Kaplan, N.S., 1986. Development of physical education course in Turkey and Ankara in eleven secondary school status. Ankara University Faculty of Educational Sciences, Master Thesis, Ankara. pp: 26

Kocer, H.A., 1970. Emergence and development of modern education in Turkey (1773-1923). Istanbul: Department of Education Publications. pp: 40

Mengutay, S., 1992. Artistic gymnastics. Istanbul: Instructional Methods and Assistive Shapes of Basic Technical Movements. pp: 3-5.

Özçakır, S. and I. Yıldıran, 2016. Contemporary transformations in physical education during the constitutional period (1908-1918). Ankara University, Faculty of Sport Sciences, 14(1): 15-28.

Tarcan, S.S., 1928. Terbiye-i Bedenniye Tarihi. İstanbul: Devlet Yazıcı. pp: 140-141.

Tayga, Y., 1990. Overview of Turkish sport history. Ankara: GSGM Publications.

Tekil, S., 1985. Galatasaray tarihi 1905-1985. İstanbul: Ekol Offset. pp: 5-12.

Unat, F., 1964. A historical perspective on the development of Turkish education system. Ankara: Milli Eğitim Basımevi.

Unat, F.R., 1964. An historical overview on the development of Turkish education system. Ankara: Milli Eğitim Basımevi. pp: 36.

Ylldıran, I., 1996. The appearance of some sports activities in the early periods of Turkish culture in terms of application causes and functions. Journal of Physical Education and Sport Sciences, 1(2): 47-57.

Yucel, H.A., 1994. Secondary education in Turkey, H. A. Yücel Corpus III. Ankara: Ministry of Culture Publications. pp: 258-360. 